\title{
FACTORS THAT DETERMINE THE SUCCESS OF IMPLEMENTING VILLAGE FUND PROGRAM POLICIES IN JENEPONTO REGENCY
}

\author{
Nurdin Nara* \\ Public Administration, Faculty of Social and Political Sciences, \\ Hasanuddin University, Indonesia \\ *Corresponding Author
}

\begin{abstract}
This article discusses the Factors That Determine the Success of the Implementation of Village Fund Program Policies in Jeneponto Regency. This type of research is qualitative research. This research was conducted in Jeneponto Regency, from mid-2017 to January 2018. Jeneponto Regency consists of 11 districts with 82 villages and 31 sub-districts. The results show that the size and objectives that affect the implementation of the village fund program have not achieved optimal results, socialization to the community regarding Village Fund policies and programs is rarely carried out, and even in some villages, it does not involve the community at all. Low levels of education, inadequate experience, and low allowances or inadequate income for officials also hinder the achievement of program objectives, so the recruitment of competent officials and welfare need to be considered. Regarding the attitude of the implementers, there are several driving and inhibiting factors, the available funding sources are limited and the attitude of the implementers, especially the activity implementation team, is not functioning so that program delays are difficult to avoid. Fund supervision has not been optimal, although so far there have been many reports of misuse of village funds, late disbursement, and deductions of village funds but there have been no sanctions or corrective actions including former village heads who still control village assets and efforts to increase community participation must be addressed wisely by the village leader or head by approaching the community persuasively and providing understanding so that the community is willing to participate in the progress of the village.
\end{abstract}

Key words: Policy Implementation, Village Fund, Empowerment Program

Cite this Article: Nurdin Nara, Factors that Determine the Success of Implementing Village Fund Program Policies in Jeneponto Regency, International Journal of Management, 11(12), 2020, pp 1800-1809.

http://iaeme.com/Home/issue/IJM?Volume $=11 \&$ Issue $=12$ 


\section{INTRODUCTION}

Policy implementation is influenced by various factors, both individual factors, and organizational factors, so that many programs have been made by the government to overcome various public problems which in practice have failed. The number of failures in policy implementation has led to new studies in policy studies, namely policy implementation studies.

A policy can fail because of the unclear content or purpose of a policy or the inaccuracy between what was decided was different from the realization (Matland, 1995). As stated by Grindle (1980), the so-called implementation as a political and administrative process states that the success of implementation is measured by two things, namely the process, by questioning whether the implementation of the policy is as determined (design) by referring to the policy action. Whether the policy objectives are achieved by looking at two factors, namely the impact on society individually and in groups and the level of change that occurs and the acceptance of the target group and the changes that occur.

O'Toole (1986) argues that the success of policy implementation is determined by the content of the policy which includes: Interset affected, Type of benefits, Extend of change envisioned, site of decision making, programs implementors, resources and commitments and the context of policy implementation is power, interest, and strategies of actors involved, institutions and regime characteristics, compliance and responsiveness. Through this unique and comprehensive approach, a policy will have an impact on the success of both individuals and groups as a mutually desired change.

At the implementation stage, there are various forces that will influence each other, both those that encourage/smoothen the facilitating conditions, and the forces that hinder the impeding conditions for implementing the program or project (Guohui \& Eppler, 2008). The supporting factors are the commitment of political leaders, organizational capacity, the commitment of implementors: If the generals are ready to move to captain and troops will follow, interest group support. And the inhibiting factors are the number of actors involved, there are multiple commitments or loyalties, the complexity inherent in the projects themselves intrinsic complexity, too many levels of decision making (Vaughan, 2001; Mabert et al., 2003; Aliye, 2020; Daniguelo, 2020).

In order for an implementation process to obtain the results expected by service recipients, there must be transactional communication between the plan and implementation and vice versa. The implementation does not have to be rigid in following the plan but can be adapted to the local situations at hand. On the other hand, implementation cannot run without a clear plan (Birkland, 2019).

This transaction also takes place between actors involved in the implementation process, as well as between implementers and community groups, because community groups are usually plural, consisting of various interest groups with different socio-cultural backgrounds and perhaps different interests, so it is necessary consensus or collective agreement regarding values which is the basis of an aspirational public policy orientation should be the concern of all parties because public policies are in the interest of the public. Factors that support and hinder the implementation of the village fund program policy in Jeneponto Regency.

\section{METHODS}

This type of research used in this research is qualitative research. The scope and focus of this research is the study of the implementation of the Village Fund program in order to improve governance, development, and community welfare. This research was conducted in Jeneponto 
Regency, from mid-2017 to January 2018. Jeneponto Regency consists of 11 districts with 82 villages and 31 sub-districts.

For this reason, we set Turatea District as a lowland area and Rumbia District as a highland / mountainous area. And then determined 3 villages for each district, namely: Turatea District. Rumbia Subdistrict designated as research locations are Bontotiro Village, Lebang Manai Utara Village, and Tompobulu Village. This type of data collection uses data triangulation which is carried out by combining in-depth interviews, focus group discussion (FGD) observations, or directly observing the object of the problem and documentation study.

The research informants are as follows: (1) Elements of the Regional Government/Community and Village Empowerment Service, (2) DPRD (Regional People's Representative Assembly) members (commission III), (3) Camat and Staff, (4) Village Heads, (5) Village Officials, (6) Members of the BPD (Village Consultative Body)/Hamlet Head, (7) Village Development Cadres/NGOs/Community Leaders.

The data processing process is a follow-up after collecting data. In this study, the techniques used in the data processing process were moving between data collection, data reduction, presentation, and conclusion/verification.

\section{RESULTS AND DISCUSSION}

\subsection{Standard and Purpose}

In the village fund program measures and objectives have been determined, but these measures and objectives are not clear so that program implementers can interpret them differently. So what is important for them is to carry out better the four objectives referred to, namely the administration of government and community services better than before and many development activities. However, community development and empowerment are still considered not optimal according to the research results previously described (Gittell \& Vidal, 1998).

This is in line with the results of Apung Widadi's research that in almost all research villages in Sumatra and NTT (East Nusa Tenggara), the implementation of the village fund program is more for physical activities, while community empowerment programs are still lacking or even non-existent.

Based on the description above, the size and objective variables that affect the implementation of the village fund program have not yet achieved optimal results, then a research result proposition can be prepared that the standard variables (size) and program objectives are not in accordance with the targets or plans to be achieved, especially community guidance and empowerment. So that in the future these two objectives need to be given attention by providing adequate resources and funds so that the program objectives are achieved.

\subsection{Communication}

The driving factor so that implementation can run smoothly, if: (1) There is socialization carried out by the District, District and Facilitator Teams, (2) Information attainment from policymakers to policy implementers runs smoothly, (3) Consistency factor in achieving messages/orders policy means there are no conflicting orders (Anugraha \& Fernando, 2017).

Meanwhile, the inhibiting factor in this communication is that socialization to the community regarding Village Fund policies and programs is rarely carried out and even in some villages it does not exist or does not involve the community at all, so that the community's understanding of the DD program is lacking and non-existent. This resulted in 
difficulty getting community participation in the implementation of the Village Fund program and in monitoring activities. (Van Meter \& Van Horn, 1980).

Based on the description of communication which is one of the driving and inhibiting variables for the implementation of the village fund program, the communication variables can be compiled in the research result proposition, namely socialization, program clarity and consistency of program planning and implementation that have not been carried out properly, which is marked by a lack of socialization of the fund program. Village to community and government regulations always fluctuate and tend to be inconsistent. Therefore, the consistency of the government and the incessant socialization is essential for the success of the village fund program.

\subsection{Resources}

In the implementation of the village fund program, resources are very important, especially human resources and financial resources, which are the main driving variables for running an efficient and effective program effectively and efficiently. When resources are less than optimal, it can hamper existing programs. So the availability and integration of resources that are actually available can facilitate program implementation (Hogwood \& Gunn, 1984).

Furthermore, Mazmanian \& Sabatier (1983) stated that in running a program, the resources involved must-have capabilities in their fields. If we pay attention to the level of education as one of the office indicators that affect the ability of human resources, that on average village officials in the highlands only graduate from high school and junior high school and have minimal experience because all of these officers are appointed by the current Village Head. Therefore, staff appointments in the bureaucracy are in accordance with their abilities and are given adequate incentives so that the support of the apparatus is maximized in carrying out their duties (Edwar III, 1980).

After that, assign tasks and responsibilities in accordance with their respective fields in terms of flexible organizational structures, adequate resources, and the presence of political and community support so that program implementation can be carried out more effectively (Cheema \& Rondinelli, 2007). The same thing was found by Sahrani in his research on Village Fund Allocation in Kutai Kartanegara that sources of funds were still the main obstacle for the smooth running of the village development program.

In addition, there are still a number of problems faced in implementing the village fund program, namely the low income of the village head and all its apparatuses. According to the results of the research, the income and benefits of the village head are in accordance with the Regent's Decree No. 6 of 2017 concerning the Village Head's Income and Allowances and its apparatus, namely the Village Head in the amount of Rp. 2,000,000.- - Rp. 2,500,000.- per month, and the equipment is between Rp. 1,500,000.- - Rp. 2,000,000. and BPD and Hamlet Head allowances between Rp. 500,000 to Rp. 1,000,000.- depending on the policy of the Village Head which is paid every 6 months, namely in July and December.

From the results of research in the relationship between resources and the implementation of DD (differential diagnosis), there are several inhibiting factors, namely the low education of village officials who generally only graduated from junior high school and some still graduated from junior high school and are not supported by adequate experience, low salaries/benefits obtained so that village officials must divide their time looking for additional work for family needs, as well as the absence of adequate village income support, resulting in a lack of financial support as the main resource in implementing policies and programs. This is what policymakers need to realize in order to provide greater financial resources to villages so that the program can run smoothly (Kaboski \& Townsend, 2005). 
Based on the description of resources which are one of the inhibiting variables for the implementation of the village fund program, the propositions of the research results can be compiled in the research result propositions, namely low levels of education, lack of experience and low allowances or inadequate income of officials who also hinder the achievement of program objectives, then recruitment of competent officials and welfare need to be considered.

\subsection{Executor's Stance}

The results of this study indicate that there is a theoretical suitability in implementation with the variables studied, where the behavior of program implementers is related to attitudes where perception, response, and action are mental readiness for the implementer of the village fund program, so what is important is learned in the organization through experience and has a certain influence on responsiveness. someone against other people, objects, and situations related to it. According to Edwar III (1980), in organizations there are tendencies or it can be said that the attitude or disposition of the executing apparatus.

In principle, perceptions, responses, and actions in the implementation of the programs that have been carried out, but have not been very good in implementation. Based on the results of the research, there is an attitude of the implementer who is not responsive to various complaints from the community, so that improvement from all aspects through conscious action is a form of responsibility as stated by Meter \& Van Horn (1975) that: "The 'disposition' or response of the implementers, involving three elements: 'their cognition of the policy, the direction of their response to it and the intensity of that response "can be interpreted as the tendency of the responsibility of the policy implementer which includes awareness, direction and intensity of responsibility for the implementation of public policies.

Nugroho (2015) also conveyed the important role of the implementer's attitude in the implementation of a policy, namely: "If the implementers pay attention to a specific policy, then it is possible for the implementor to do as intended by decision-makers. However, when the attitude or perspective of the implementor differs from that of the decision-makers, the process of implementing a policy becomes definitely more difficult. This shows that even though policy implementers have the ability to implement a policy, when the implementers do not agree with the policy, it will lead not to do so.

In relation to the implementation of the Village Fund policy, the results of the research on the attitudes of the implementers are several driving and inhibiting factors, the available funding sources are limited and the attitude of the implementers, especially the activity implementation team, is not functioning so that program delays are difficult to avoid.

Based on the description of the attitude variable which is one of the driving and inhibiting variables towards the implementation of the village fund program, a research result proposition can be drawn up, namely that the program manager is less responsive and does not respond to questions from the community and is slow in making decisions, delays in distributing village funds results in The delay in implementing the village fund program requires commitment, dedication and integrity, and discipline of officials in program implementation.

\subsection{Bureaucracy Structure}

The definition of bureaucracy refers to an organization that is intended to exert energy regularly and continuously, to achieve a certain goal. In other words, bureaucracy is a hierarchical organization that is rationally established to coordinate people's work for the benefit of carrying out administrative tasks. Lewis A. Coser and Bernard Rosenberg (in Soekanto, 1982). 
Within the organizational structure, there needs to be a top leader who determines the direction of policy, and is responsible according to the organizational structure in an orderly and well-coordinated manner. The results showed that the management of the village fund program, especially the process of submitting funds for disbursement and oversight, had too many levels to go through, namely, 12 items as previously described and there was a delegation of supervisory authority to the PMD Office of Jeneponto Regency so that the Subdistrict Heads felt less functioning in relation to the implementation of the funding program. village even though they are closer to the village. If the division of tasks is still overlapping and there is no clarity so that the results achieved are not optimal. (Girendle, 1980).

In implementing a policy, the existing bureaucratic structure should also support and try as much as possible in order to achieve the goals set out in the existing policies, because good and good policies at the conceptual level are not necessarily successful and beneficial according to the objectives if implemented without the support of all actors. and it can result in failure if it does not pay attention to all the influencing factors, both those that encourage and hinder the implementation of a policy.

To boost the performance of the bureaucratic structure in a better direction, there are 2 things that need to be done, namely 1) making a more flexible standard operation procedure (SOP), 2) carrying out fragmentation, namely spreading the responsibilities of various activities or programs to the units in accordance with their respective fields. (Edwar III, 1980)

According to the results of the research in the context of implementing the village fund program, an organizational structure has been formed in the form of a Village Village activity implementation team (TPK) in all villages, namely the Village Head as the person in charge of activities, the village secretary as the activity executive coordinator, the Head of financial affairs as the village treasurer and assisted by Village Community Institutions.

To ensure the smoothness of the formation of the organizational structure, the Jeneponto District Community Empowerment Service (PMD) was given special authority in accordance with the Regent's Decree No. 67 of 2017 concerning the allocation and control of village funds and the allocation of village funds in Jeneponto Regency.

Based on the description of the bureaucratic structure variables which are one of the driving and inhibiting variables on the implementation of the village fund program, a research result proposition can be drawn up, namely, that policymaking in allocating and controlling the Village Fund program is delegated specifically from the Regent to the PMD (Village Community Empowerment Service) Office ineffective because of the vast area and the problem is very complex, while the sub-district head and staff as the apparatus closest to the village government are less functioning, so it is necessary to return the duties and functions of the subdistrict head as government controller and supervision in their respective regions so that the bureaucratic structure is more effective and efficient so that the PMD Office is more in nature. coordinative at the district level. Because if there are too many actors who play it can hamper the program or hamper implementation. Warwick (in Gratitude Abdullah, 1988).

\subsection{Environment}

The environment is defined as all factors that are outside the organization, or all that are outside the organizational boundaries. This environment includes the general environment (general environment) that affects the organization indirectly, or is less directly felt, such as political, economic, social, cultural and legal conditions and a specific environment (specific environment) that has an influence that is felt directly like the customer. , suppliers, competitors, government, trade unions, trade associations, and pressure groups. Robbins (in Keban, 2014) 
Based on the results of the research, the supervision of funds has not been optimal, even though until now there have been many reports of misuse of village funds, late disbursements, and deductions of village funds but there have been no sanctions or corrective actions including former village heads who still control village assets (village offices) in the District Rumbia Jeneponto Regency.

Likewise, the commitment of the supervisory apparatus and leadership is still low due to the lack of direct monitoring in the field. As for the officials who came to the village, only officials from the Inspectorate and officers of the Jeneponto District Community Empowerment Service (PMD) visited the village head's house to ask about development activities in the village that were being carried out, did not directly check and check the results of the work properly. This is in line with the results of interviews that have been described previously that the supervision of the village fund program is very lacking so that many projects are carried out in random order, break down quickly, and even are not completed, especially the construction of farm roads.

Apart from that, political factors, such as the election of the village head, also greatly influence the smooth running of governance and development in the village. For example, the village head (incumbent) who is still running for the Pilkades and loses, so some village assets such as the village office, the farmer's workshop that he built while being the Village Head do not hand over the elected village head.

This situation occurred in several in Rumbia District, one of which was the research location, namely in the Village of Lebang Manai Utara, which since the 2012 Pilkades until now has not had a village office because it is controlled by a former village head who was in the Pilkades. Likewise in Bontotiro Village, Rumbia District, which held a replacement of the Village Head through the Pilkades several years ago and the Pilkadesa simultaneously in September 2017 which had a bad impact on government organization and the implementation of Village development, including: a. Lack/no service to the community, b. Lack of village development activities, c. Village officials and the Village Consultative Body (BPD) do not receive allowances and others.

So the political factor, namely the replacement of leadership in the case of Pilkades has caused many problems both in Bontotiro Village and in Lebang Manai Utara Village, Rumbia District, even as a result of Pilkades there were 7 villages in Rumbia District that did not have a village office because the former Village Head who lost the Pilkades still controlled village office and there is no power for the authorities to resolve the problem. And another problem is the conflict between families due to the election of the village head which has implications for program implementation.

Based on the description of the environmental and political variables in the village which is one of the driving and inhibiting variables for the implementation of the village fund program, a research result proposition can be prepared, namely that there is still a community and village political elites who are oppositional and selfish in implementing the program, so togetherness is needed., commitment, coordination, and harmonization between village heads and former village heads as well as political elites in the village in order to smooth the implementation of village fund program policies for the common interest.

\subsection{National Elite Politics}

From the results of research in environmental relations, such as the condition of the community, which are generally farmers and poor, really need good government assistance, the Village Fund program is a promising source of funding to overcome various problems in the village, especially to build village facilities and infrastructure. One thing that encourages smoothness in overcoming these problems is the increasing number of village funds according 
to the Village Fund Road Map that until the end of the year the Jokowi-JK period in 2019 will reach Rp. 1.5 - 2 billion IDR per village. But the fact is that the village funds received so far are only about $40 \%$ of what they should be, so it has not been able to solve the problems that exist in the village. This has also been exacerbated by increasing prices for building materials and tools needed for program implementation, including demands for compensation for farmers' land, increasing labor wages, so that several village fund programs cannot be implemented properly.

All that can be done well if supported by the government, Imam Prasojo said that "no program will run smoothly if there is no executive and legislative support, political support in the form of a strong commitment to modernizing the bureaucracy and enforcing the law, and development must be provided not only. by the government, especially the president or governors and regents in the regions as Head of government but also political institutions such as the People's Representative Council (DPR), Audit Board of the Republic of Indonesia (BPK), and Supreme Court (MA) at the center and DPRD in the regions (Imam Prasojo, 2014).

Based on the research findings as described above, the authors compile the research result proposition, namely if you want the village fund program to be successful, it requires strong support and commitment from the executive and legislative parties both at the central and regional levels.

\subsection{Community Participation}

The success of national development in general and village development, in particular, is not only determined by the government and its officials but also by the amount of understanding, awareness, and participation of all levels of society, especially in relation to the implementation or implementation of Village Fund Program policies.

Furthermore, participation is an important thing in development and even becomes one of the goals of development itself, in another sense that community participation is needed both in the context of society as the subject or object of development.

Thus a policy that is accepted or adopted by the community, then the community will provide feedback in the form of support or even rejection of the policy if there is no match between the program and its needs. If the policy provides incentives, the community will support the policy, but if the policy does not provide incentives or even disincentives, there will be a rejection of the policy if he accepts the results will not be optimal. (Subarsono, 2005).

Efforts to increase community participation must be addressed wisely by the village leader or head by approaching the community persuasively and providing understanding so that the community is willing to participate for the sake of village progress and development and the Village Head as the spearhead of development can adjust to current conditions which are all money and hardly some are free. And it should be noted that land is the only source of income, even if there are not many people with more economic capacity, they don't want to give away their land for free. This is one of the variables that greatly influences the success of the program, while the government still always imagines high community participation in development. This assessment has shifted to the current conditions, where people with increasingly limited resources, the more difficult it is for them to provide something very valuable, which under the New Order regime was called community participation in development. And this is a lot of evidence in the Jeneponto Regency that their lands can be used to build public facilities such as schools and markets, but now no one is willing to do that anymore. 
Based on the description of the community participation variable which is one of the driving and inhibiting variables for the implementation of the village fund program, a research result proposition can be drawn up, namely that no more people are willing to participate in the form of providing materials/assets, if not compensated because it is the only one. their source of income, so if anything is needed then it must be purchased or at least compensated so that they can find better land.

\section{CONCLUSION}

Determination of program standards and objectives is very complex while the village funds are limited, lack of socialization is marked by a lack of community knowledge of the objectives of village funds, differences in the information conveyed by implementation in the field and, for example, many projects that are delivered are not in accordance with reality or less, limited resources, namely village officials with a low level of education, namely generally $92.7 \%$ have junior and senior high school education, and only $7.3 \%$ have a bachelor's degree and only 1 master is not active in carrying out tasks, perceptions, responses and actions (attitude) is not optimal, because it is still slow in implementing the program even though there are many complaints from the community that there is no response from village government officials. The organizational structure and bureaucracy are considered convoluted, namely, the disbursement mechanism is very slow and the financial accountability is complicated, the community environment has not synergized well because, the village head goes out on his own and the village political elite becomes the opposition and "blocks" the smooth implementation of the village fund program, the leadership of the political elite those at the center, namely the President and the House of Representatives (DPR) are still half-hearted in building villages because the realization of village funds amounting to $10 \%$ of and outside transfers to regions has not matched the reality. And the political elite in the regions, namely the Regional People's Representative Council (DPRD), the Regent, and his staff, too. Community participation or support in the form of funds, personnel, materials, or the like in the framework of implementing development programs cannot be expected free of charge from the community because they are the ones who need assistance. So if the need for land, labor, and the like can be obtained by being paid according to the price and agreement.

\section{REFERENCES}

[1] Aliye, A. (2020). Corporate Social Responsibility and Business-Community Relations in Africa: the Case of Ethiopia. Journal of Advanced Research in Economics and Administrative Sciences, 1(2), 77-90.

[2] Anugraha, I. S., \& Fernando, F. (2017). The Implementation of PINDU (Center for Information and Complaints) Program Innovation Policy in Pinrang District. Matra Pembaruan: Jurnal Inovasi Kebijakan, 1(1), 55-63.

[3] Birkland, T. A. (2019). An introduction to the policy process: Theories, concepts, and models of public policy making. Routledge.

[4] Cheema, G. S., \& Rondinelli, D. A. (2007). Decentralizing governance: emerging concepts and practices. Brookings Institution Press.

[5] Daniguelo, A. (2020). Ontology in Public Administration Includes Potential, Positivism and Rationalism Approaches. Journal La Sociale, 1(6), 41-46.

[6] Edward III, G. C. (1980). Implementing Public Policy. Washington: Congressional Querterly.

[7] Gittell, R., \& Vidal, A. (1998). Community organizing: Building social capital as a development strategy. Sage publications. 
[8] Grindle, M. S. (1980). Politics and Policy Implementation in the third world. Princeton University Press.

[9] Guohui, S., \& Eppler, M. J. (2008). Making strategy work: A literature review on the factors influencing strategy implementation. Handbook of Strategy Process Research, 252-276.

[10] Hogwood, B. W., \& Gunn, L. A. (1984). Policy analysis for the real world. Oxford University Press, USA.

[11] Kaboski, J. P., \& Townsend, R. M. (2005). Policies and impact: An analysis of village-level microfinance institutions. Journal of the european economic Association, 3(1), 1-50.

[12] Mabert, V. A., Soni, A., \& Venkataramanan, M. A. (2003). Enterprise resource planning: Managing the implementation process. European journal of operational research, 146(2), 302-314.

[13] Matland, R. E. (1995). Synthesizing the implementation literature: The ambiguity-conflict model of policy implementation. Journal of public administration research and theory, 5(2), 145-174.

[14] Mazmanian, D. A., \& Sabatier, P. A. (1983). Implementation and public policy. Scott Foresman.

[15] O'Toole Jr, L. J. (1986). Policy recommendations for multi-actor implementation: An assessment of the field. Journal of public policy, 181-210.

[16] Van Meter, D. S., \& Van Horn, C. E. (1975). The policy implementation process: A conceptual framework. Administration \& Society, 6(4), 445-488.

[17] Vaughan, P. J. (2001). System implementation success factors; it's not just the technology. In CUMREC Conference (Vol. 15). 